\title{
Highly time-resolved chemical characterization of atmospheric fine particles during 2010 Shanghai World Expo
}

\author{
X.-F. Huang ${ }^{1}$, L.-Y. He ${ }^{1}$, L. Xue ${ }^{1}$, T.-L. Sun ${ }^{1}$, L.-W. Zeng ${ }^{1}$, Z.-H. Gong ${ }^{1}$, M. Hu ${ }^{2}$, and T. Zhu ${ }^{2}$ \\ ${ }^{1}$ Key Laboratory for Urban Habitat Environmental Science and Technology, School of Environment and Energy, Peking \\ University Shenzhen Graduate School, Shenzhen, China \\ ${ }^{2}$ State Key Joint Laboratory of Environmental Simulation and Pollution Control, College of Environmental Sciences and \\ Engineering, Peking University, Beijing, China
}

Correspondence to: L.-Y. He (hely@pku.edu.cn)

Received: 13 November 2011 - Published in Atmos. Chem. Phys. Discuss.: 11 January 2012

Revised: 28 April 2012 - Accepted: 22 May 2012 - Published: 5 June 2012

\begin{abstract}
Shanghai, with a population of over 20 million, is the largest mega-city in China. Rapidly increasing industrial and metropolitan emissions have deteriorated its air quality in the past decades, with fine particle pollution as one of the major issues. However, systematic characterization of atmospheric fine particles with advanced measurement techniques has been very scarce in Shanghai. During 2010 Shanghai World Expo, we deployed a high-resolution timeof-flight aerosol mass spectrometer (HR-ToF-AMS) and a single particle soot photometer (SP2) in urban Shanghai between 15 May and 10 June 2010 to measure fine particles with a high time resolution. The 4-min resolution $\mathrm{PM}_{1}$ mass concentration ranged from 5.5 to $155 \mu \mathrm{g} \mathrm{m}^{-3}$, with an average of $29.2 \mu \mathrm{g} \mathrm{m}^{-3}$. On average, sulfate and organic matter (OM) were the most abundant $\mathrm{PM}_{1}$ components, accounting for 33.3 and $28.7 \%$ of the total mass, respectively, while the fraction of nitrate showed an increasing trend with the increasing $\mathrm{PM}_{1}$ loading, indicating the photochemical nature of high fine particle pollution in Shanghai. Taking advantage of HR-ToF-AMS and SP2, OM was found to have an average $\mathrm{OM} / \mathrm{OC}$ ratio (organic matter mass/organic carbon mass) of 1.55 and black carbon (BC) had an average number fraction of internally mixed $\mathrm{BC}$ of $41.2 \%$. Positive matrix factorization (PMF) analysis on the high resolution organic mass spectral dataset identified a hydrocarbon-like (HOA), a semi-volatile oxygenated (SV-OOA), and a lowvolatility oxygenated (LV-OOA) organic aerosol component, which on average accounted for 24.0, 46.8, and $29.2 \%$ of the total organic mass, respectively. The diurnal patterns of them with interesting time delay possibly implied a photo-
\end{abstract}

chemical oxidizing process from HOA (and/or its concurrently emitted gaseous organic pollutants) to SV-OOA to LVOOA. Back trajectory analysis indicated that the northwesterly continental air mass represented the most severe pollutant regional transport condition with the highest nitrate and SV-OOA fractions. In addition, the results in Shanghai were compared with similar measurements performed recently in other mega-cities in the world.

\section{Introduction}

Shanghai, with a population of over 20 million, is the largest commercial and industrial city in China, as well as a famous mega-city in the world. Its air quality has been deteriorated in the past decades due to rapidly increasing industrial and metropolitan emissions. For example, Ye et al. (2003) reported an annual average $\mathrm{PM}_{2.5}$ concentration of about $60 \mathrm{\mu g} \mathrm{m}^{-3}$ in Shanghai in 1999-2000, while this value reached up to about $90 \mu \mathrm{g} \mathrm{m}^{-3}$ in 2005-2006 (Y. Feng et al., 2009). As the adverse health impacts of air pollution increase rapidly with the population size of a city (Parrish and Zhu, 2009) and the air pollution output from mega-cities are now believed to be globally important (Crounse et al., 2009), air pollution characterization in Shanghai metropolitan areas is of great interest.

The 2010 World Expo was hosted in Shanghai during 1 May-31 October 2010, which was another major event in China after the 2008 Beijing Olympic Games. In order to improve the air quality during the World Expo, the Shanghai 
government implemented a series of air pollution control measures before the event, including reducing coal burning emissions from power plants, strict regulations on vehicular emission standards, closing high-emitting factories, reducing volatile organic compound (VOC) emissions, etc. The neighboring Jiangsu and Zhejiang provinces also enacted control measures to decrease regional transport of air pollutants to Shanghai. In addition, open field biomass burning was strictly forbidden as a special temporary measure during the World Expo.

Since fine particles play a key role in air pollution in Shanghai (Chan and Yao, 2008), thorough in-situ characterization of the chemical and physical properties of atmospheric fine particles is essential for evaluation of the emission control measures during the 2010 Shanghai World Expo. As part of the project of Air Quality Monitoring Campaign for 2010 Shanghai World Expo supported by Shanghai government, we deployed a high-resolution time-of-flight aerosol mass spectrometer (HR-ToF-AMS) and a single particle soot photometer (SP2) in urban Shanghai to measure chemical and physical characteristics of ambient submicron particles with high time resolution. Previous aerosol studies in Shanghai were mostly based on filter sampling with a coarse time resolution like a day, which cannot match the faster variation of aerosol properties in the atmosphere. This paper summarizes and analyzes the findings based on the advanced on-line measurement techniques during the 2010 Shanghai World Expo, in order to reveal both the basic characteristics of fine particle pollution in this mega-city and some unique features related to the emission control measures during the World Expo.

\section{Experimental methods}

\subsection{Sampling site and period}

Shanghai $\left(121.53^{\circ} \mathrm{E}, 31.23^{\circ} \mathrm{N}\right)$ is located in the east of the Yangtze River Delta region of China, facing the East China Sea. It belongs to the northern subtropical monsoon climate, with northwestern wind prevailing in the winter while southeastern wind in the summer. The sampling site was located on the roof of a 6-floor building of Shanghai Pudong Environmental Monitoring Station, which was in the eastern part of Shanghai urban areas and about $8 \mathrm{~km}$ far to the northeast of the World Expo Park. The surroundings of this site were mainly a residential and business area. The sampling campaign lasted from 15 May to 10 June 2010 after the opening ceremony of the World Expo, which was a transition season from spring to summer in Shanghai with a mean ambient temperature of $21^{\circ} \mathrm{C}$ and a mean relative humidity of $66 \%$. A $\mathrm{PM}_{2.5}$ cyclone inlet was set up on the roof to sample outdoor air into the instrument room through a copper tube with a flow rate of $101 \mathrm{~min}^{-1}$.

Atmos. Chem. Phys., 12, 4897-4907, 2012

\subsection{HR-ToF-AMS operation and data processing}

An Aerodyne high-resolution time-of-flight aerosol mass spectrometer (HR-ToF-AMS) was deployed in the instrument room to measure particulate matter, typically referred to as non-refractory $\mathrm{PM}_{1}$ (NR-PM ${ }_{1}$, Canagaratna et al., 2007), with a flow rate of $80 \mathrm{ml} \mathrm{min}^{-1}$. The detailed instrumental description of HR-ToF-AMS was shown by DeCarlo et al. (2006). During the campaign, the HR-ToF-AMS operated in a cycle of 2 modes every 4 min, including: 2 min Vmode to obtain the mass concentrations of the non-refractory species, in which there was $30 \mathrm{~s}$ time for PToF (particle timeof-flight) mode to determine size distributions of species; 2 min W-mode to obtain high resolution mass spectral data. The HR-ToF-AMS was calibrated for inlet flow, ionization efficiency (IE), and particle sizing at the beginning, middle and end of the campaign following the standard protocols (Jayne et al., 2000; Jimenez et al., 2003; Drewnick et al., 2005). The IE calibration used size-selected pure ammonium nitrate particles of 350 and $400 \mathrm{~nm}$ and the size calibration used mono-disperse polystyrene latex (PSL) spheres (Duke Scientific, Palo Alto, California, USA) with nominal diameters of $100-700 \mathrm{~nm}$ (density $\left.=1.05 \mathrm{~g} \mathrm{~cm}^{-3}\right)$.

Mass concentrations and size distributions of NR$\mathrm{PM}_{1}$ species measured by HR-ToF-AMS were calculated using the methods outlined by DeCarlo et al. (2006). Standard ToF-AMS data analysis software packages (SQUIRREL version $1.51 \mathrm{H}$, and PIKA version $1.10 \mathrm{H})$ downloaded from the ToF-AMS-Resources webpage (http://cires.colorado.edu/jimenez-group/ ToFAMSResources/ToFSoftware/index.html) were used to generate unit and high-resolution mass spectra from the $\mathrm{V}$-mode and W-mode data respectively. For mass concentration calculations, an empirical particle collection efficiency (CE) factor of 0.5 was used to account for the incomplete detection of species due to particle bouncing at the vaporizer (Canagaratna et al., 2007; Huang et al., 2010; He et al., 2011). The values of relative ionization efficiency (RIE) used in this campaign were 1.2 for sulfate, 1.1 for nitrate, 1.3 for chloride and 1.4 for organics (Jimenez et al., 2003; Canagaratna et al., 2007). A RIE value of 4.0 was used for ammonium based on the measurement of pure $\mathrm{NH}_{4} \mathrm{NO}_{3}$ particles. Organic elemental analysis was carried out with the methods described previously (Aiken et al., 2007, 2008).

The positive matrix factorization (PMF) analysis (Paatero and Tapper, 1994) was conducted on the high-resolution (HR) mass spectra $(\mathrm{m} / \mathrm{z}, 12-150)$ using the PMF evaluation tool developed by Ulbrich et al. (2009). The data and noise matrices input into the model were generated with the default fragmentation waves by PIKA. The noise values were calculated as the sum of electronic and Poisson ion-counting errors for the relevant high resolution ion fragment (Allan et al., 2003; Ulbrich et al., 2009). The minimum error value for the error matrix was set as the average noise value observed for ions during low signal periods. The ions of $\mathrm{H}_{2} \mathrm{O}^{+}, \mathrm{HO}^{+}$, 
$\mathrm{O}^{+}$, and $\mathrm{CO}^{+}$were not included into PMF running since they were determined according to their relationship with $\mathrm{CO}_{2}^{+}$ and thus including them in the PMF analysis can introduce additional weight to $\mathrm{CO}_{2}^{+}$(Ulbrich et al., 2009). These ions were inserted back into the mass spectra of the resulted PMF components. The weak ions with signal to noise ratios of between 0.2 and 2 were downweighted by a factor of 3 while bad ions with signal to noise ratios of $<0.2$ were removed from the analysis (Paatero and Hopke, 2003; Ulbrich et al., 2009). More technical details of the PMF analysis can be found in our previous publications (Huang et al., 2010; He et al., 2011).

\subsection{SP2 operation and data processing}

For a better mass closure measurement of fine particles in the campaign, a single particle soot photometer (SP2) (Droplet Measurement Technologies Inc., Boulder, Colorado) was used for simultaneous measurement of refractory black carbon (BC) mass concentrations, which cannot be detected by HR-ToF-AMS. The sampling flow rate of SP2 was set at $30 \mathrm{ml} \mathrm{min}^{-1}$. The technical details of SP2 have been described elsewhere (Schwarz et al., 2006, 2008b). The calibration of the SP2 was conducted with size-selected fullerene soot (Alpha Aesar, Inc., Ward Hill, MA). The volumeequivalent diameters of individual $\mathrm{BC}$ particles can be derived from the measured $\mathrm{BC}$ mass by assuming a density of $2 \mathrm{~g} \mathrm{~cm}^{-3}$. More details about the SP2 operation can be found in our previous publication (Huang et al., 2011a). The mixing state of BC was also detected by SP2, with the method of identifying internally mixed $\mathrm{BC}$ particles described in Schwarz et al. (2008b).

\section{Results and discussion}

\subsection{Composition, size distribution and mixing state}

Figure 1a shows the time series of the $\mathrm{PM}_{1}$ mass concentration (calculated as the sum of organic matter $(\mathrm{OM}), \mathrm{SO}_{4}^{2-}$, $\mathrm{NO}_{3}^{-}, \mathrm{Cl}^{-}$and $\mathrm{NH}_{4}^{+}$measured by AMS and $\mathrm{BC}$ measured by SP2) during the entire campaign. The $\mathrm{PM}_{1}$ mass concentration varied largely from 5.5 to $155 \mathrm{\mu g} \mathrm{m}^{-3}$, with an average of $29.2 \mu \mathrm{g} \mathrm{m}^{-3}$. The time series of particle volume concentration, which was calculated from the number size distribution between 15 and $600 \mathrm{~nm}$ measured with a collocated Scanning Mobility Particle Sizer (SMPS, TSI) by assuming spherical particles, was also plotted in Fig. 1a for comparison of the variation trend. The two parameters highly correlated with each other, with a linear correlation coefficient $\left(R^{2}\right)$ of 0.90 . The time series of the species concentrations were shown in Fig. 1b, with sulfate being the most abundant component (averagely accounting for $33.3 \%$ of the total mass) followed by OM (28.7\%), nitrate $(16.3 \%)$, ammonium $(13.4 \%)$, BC (6.7\%), and chloride (1.6\%), as shown in Fig. 1d. Compared with other mega-cities in the world, as shown in Fig. 1e, the average $\mathrm{PM}_{1}$ mass concentration level in Shanghai was lower than those previously measured in the other two Chinese mega-cities, i.e. Beijing in North China (Huang et al., 2010) and Shenzhen in South China (He et al., 2011), similar to in Mexico City (Aiken et al., 2009), while much higher than in New York City (Sun et al., 2011). For simplicity, the citation sources for the data of other megacities will not be shown in the following. Due to the limited sampling periods for the campaigns conducted in these cities, this concentration level comparison might not reflect the long-term conditions. As to the composition comparison, the most apparent feature is the higher fractions of sulfate in $\mathrm{PM}_{1}$ in the three Chinese mega-cities. In Shanghai, the fraction of sulfate even exceeded that of OM. This indicates that high sulfur-containing fuel plays a key role in the formation of high ambient aerosol loadings in China.

In terms of size distribution, the species measured by HRToF-AMS showed a similar accumulation mode in mean mass size distributions, peaking at a larger size of $\sim 450 \mathrm{~nm}$ in vacuum aerodynamic diameter $\left(D_{\mathrm{va}}\right)$, as shown in Fig. 1f, indicating large presence of aged regional origins (Allan et al., 2003; Alfarra et al., 2004; Zhang et al., 2005). However, the broader size distribution of OM at smaller sizes (around $200 \mathrm{~nm}$, as a hump), similar to what observed in Beijing and Shenzhen previously, indicates significant existing of fresh combustion organic particles.

Taking advantage of HR-ToF-AMS and SP2, some unique and important properties of carbonaceous aerosols can be measured. The high-resolution organic mass spectrometry allows direct calculation of carbon, hydrogen, oxygen and nitrogen fractions of OM. On average, $\mathrm{C}, \mathrm{H}, \mathrm{O}$ and $\mathrm{N}$ contributed $64.7,9.4,24.5$ and $1.3 \%$, to the total organic mass, respectively, corresponding to an $\mathrm{OM} / \mathrm{OC}$ (organic matter mass/organic carbon mass) ratio of $1.55 \pm 0.08$, which can be used as an empirical factor to convert organic carbon mass to organic matter mass in future filter-based aerosol studies in Shanghai. In addition, the $\mathrm{O} / \mathrm{C}$ atomic ratio is regarded as a good reference for oxidation state and photochemical age of organic aerosols (Jimenez et al., 2009; $\mathrm{Ng}$ et al., 2010). It varied in the range of 0.11-0.57 in the campaign, as shown in Fig. 1c, with a mean value of 0.31 , which is similar to those observed in the two Chinese mega-cities, Beijing (0.33) and Shenzhen (0.30), but a little lower than those in Mexico City (0.38) and New York (0.36). This may imply that organic aerosols in Chinese urban environments are more heavily influenced by primary emissions containing low $\mathrm{O} / \mathrm{C}$ ratio hydrocarbons.

Figure $1 \mathrm{c}$ also shows the time series of the number fraction of internally mixed BC (referred to as NIB later) detected by SP2 during the campaign. While freshly emitted $\mathrm{BC}$ is generally externally mixed with other aerosol materials, various processes in the ambient atmosphere especially condensation of secondary species would transform it to the internal mixing state. Although the internally mixed BC particles were ever reported to account for $\sim 70 \%$ in biomass 

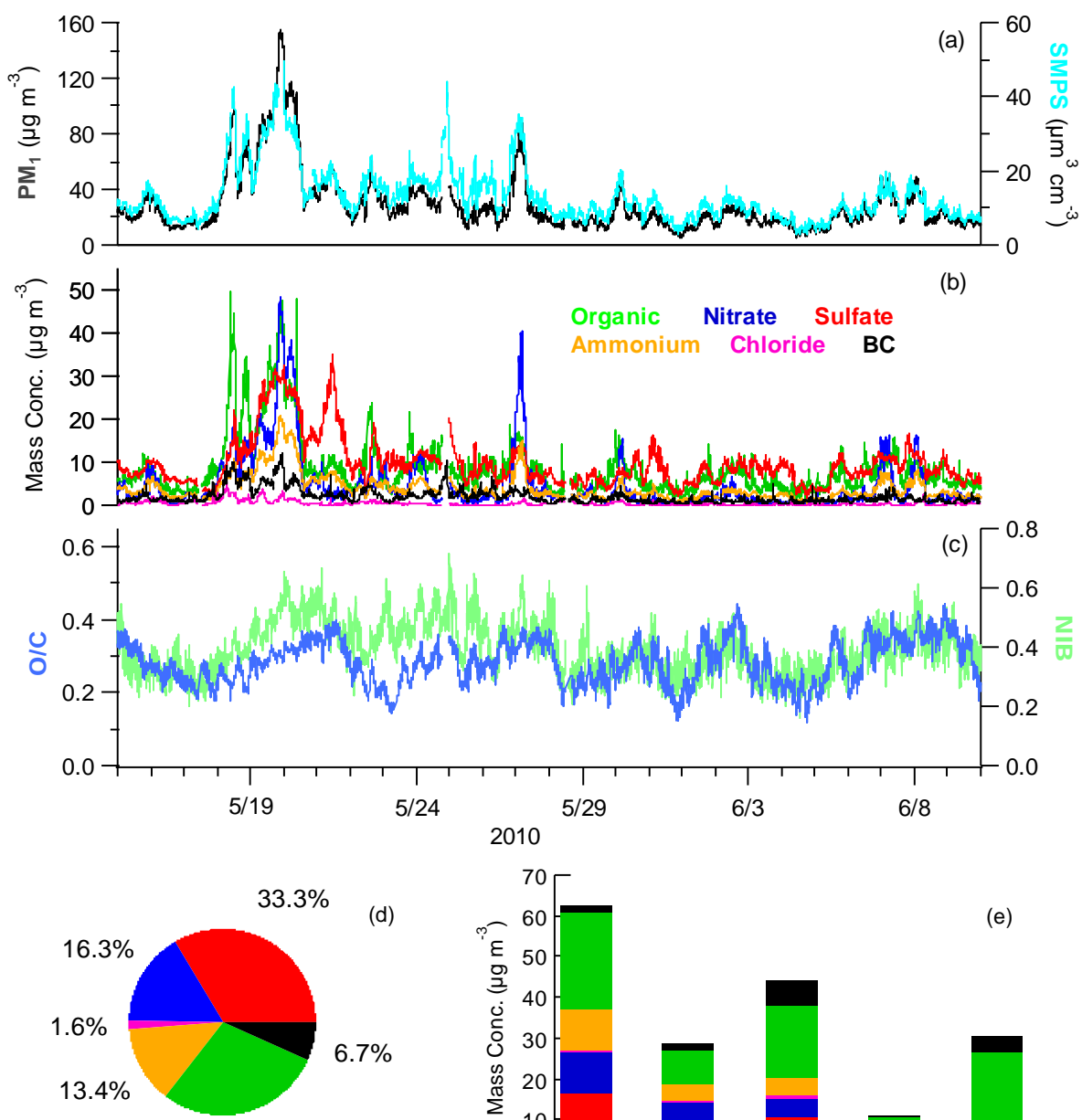

$28.7 \%$
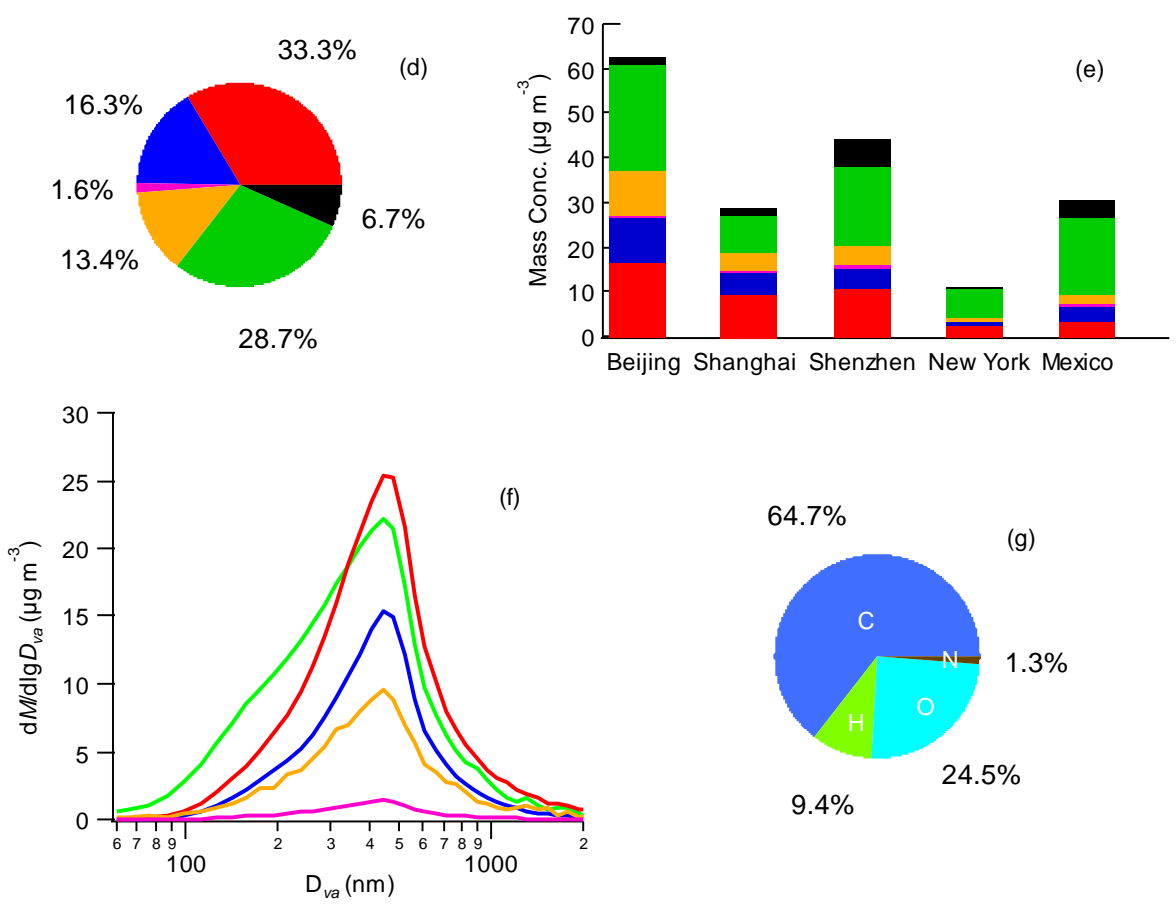

Fig. 1. The time series of (a) $\mathrm{PM}_{1}$ mass concentration by AMS species + BC and SMPS volume; (b) $\mathrm{PM}_{1}$ species concentrations; (c) O/C ratio of $\mathrm{OM}$ and number fraction of internally mixed $\mathrm{BC}(\mathrm{NIB})$; (d) the average $\mathrm{PM}_{1}$ composition; (e) the comparison of $\mathrm{PM}_{1}$ composition with other mega-cities; (f) the mean species size distributions; and (g) the average mass-based organic elemental composition.

burning plumes (Schwarz et al., 2008a), the emissions from biomass burning were strictly controlled during the World Expo and found to contribute little to fine particles by source apportionment analysis in Sect. 3.3. Therefore, the NIB can be used to roughly distinguish fresh emissions and aged par- ticles in this study. The NIB was observed to vary in the range of $16.0-71.7 \%$, with an average of $41.2 \%$, indicating that the bulk BC was dominated by fresh and thus local combustion emissions during the campaign. This result is similar to those previously observed in another mega-city in China, 
Shenzhen, with the average NIB of $40 \sim 46 \%$ (Huang et al., 2012). In addition, it is found in Fig. 1 that during the period of 19-27 May, the $\mathrm{PM}_{1}, \mathrm{BC}$, and NIB maintained at high levels, indicating that aged air mass and thus regional transport played an important role in the formation of these high pollution days. As both the $\mathrm{O} / \mathrm{C}$ ratio of OM and NIB of BC can be indicative of photochemical aging of aerosols, they did show some similar variation trends during the campaign, with a correlation coefficient $\left(R^{2}\right)$ of 0.21 .

Figure 2 shows the variation of relative contributions of different species as a function of the total mass concentration during the campaign, as well as those observed by our group previously in Beijing and Shenzhen. With the $\mathrm{PM}_{1}$ mass loading increasing in Shanghai, the relative contribution of sulfate showed a decreasing trend, the relative contribution of OM maintained at a stable level, while the relative contribution of nitrate showed an increasing trend. The increasing trend of nitrate suggests that active photochemical reactions were a key factor leading to high $\mathrm{PM}_{1}$ pollution in Shanghai. Actually, this increasing trend of nitrate was also observed in Beijing and Shenzhen, as shown in Fig. 2, indicating that high $\mathrm{PM}_{1}$ pollution in China urban environments has a common nature of photochemical smog.

\subsection{Diurnal variation patterns}

Figure 3 presents the mean diurnal variations of different species during the campaign. Sulfate showed little hourly variation, indicating that it was well mixed in the boundary layer and thus had a dominant regional origin. Both nitrate and chloride showed lower concentrations in the afternoon and higher concentrations in the early morning, suggesting that the boundary layer variation and gas-aerosol partitioning were the dominant control mechanisms for their diurnal patterns. The diurnal pattern of ammonium observed was generally the combined result of the variations of $\left(\mathrm{NH}_{4}\right)_{2} \mathrm{SO}_{4} / \mathrm{NH} 4 \mathrm{HSO} 4, \mathrm{NH}_{4} \mathrm{NO}_{3}$ and $\mathrm{NH}_{4} \mathrm{Cl}$. Since OM has both large primary and secondary origins and is also influenced by its semi-volatility, the observed diurnal pattern of OM was a complicated result. However, the concurrent increase of both the $\mathrm{OM}$ concentration and its $\mathrm{O} / \mathrm{C}$ ratio in the morning is indicative of the start of secondary organic aerosol (SOA) formation during the daytime. Identification and description of the diurnal patterns of different organic components are discussed in Sect. 3.3. BC showed two broad peaks in the morning and evening and maintained at a high level in the daytime despite of the high boundary layer, clearly reflecting the high vehicular emissions due to the World Expo traffics. The lowest hourly NIB of BC at around $8 \mathrm{a} . \mathrm{m}$. further indicates that fresh vehicular emissions contributed most largely during the morning rush hours.

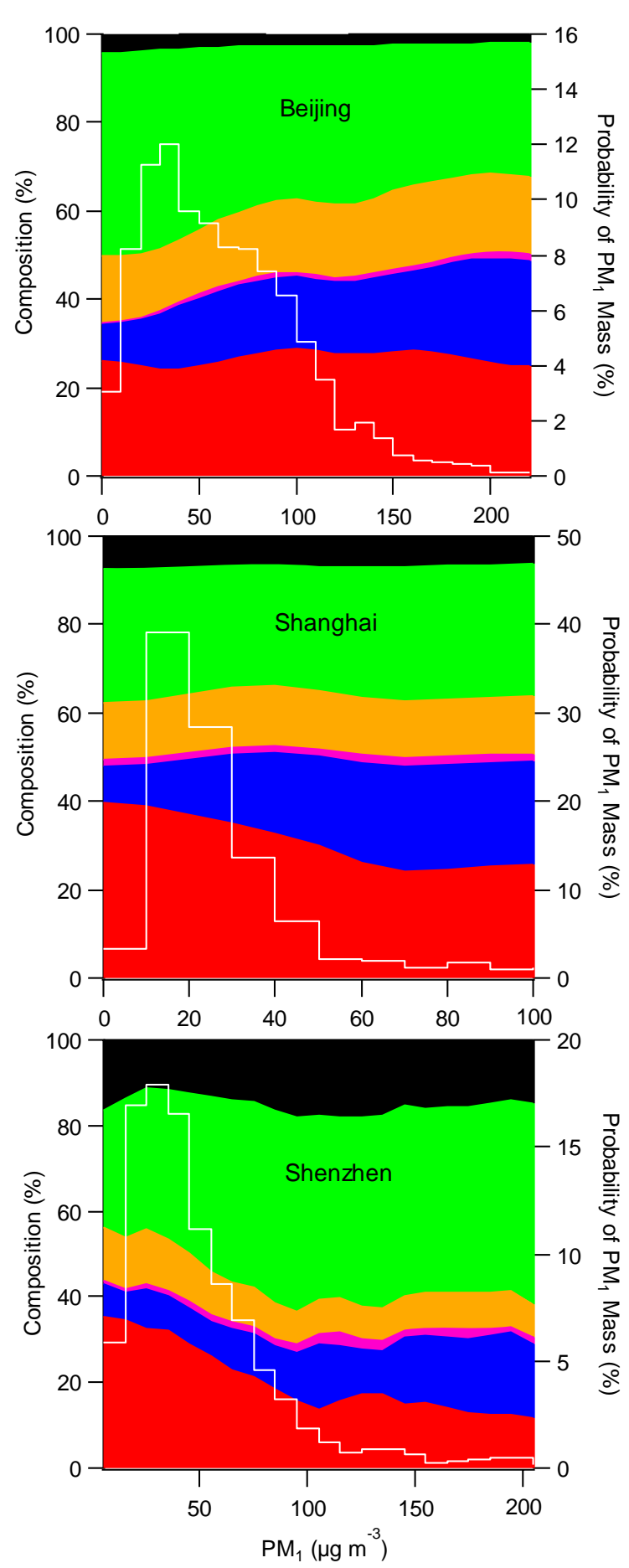

Fig. 2. The variation of percent composition with $\mathrm{PM}_{1}$ mass concentration in Shanghai, as well as in Beijing and Shenzhen.

\subsection{Organic source apportionment}

The PMF modeling based on the high-resolution mass spectrum observed in the campaign was run for 1 to 8 factors, and it was found that the PMF solutions with factor numbers greater than 3 resulted in splitting of the existing 

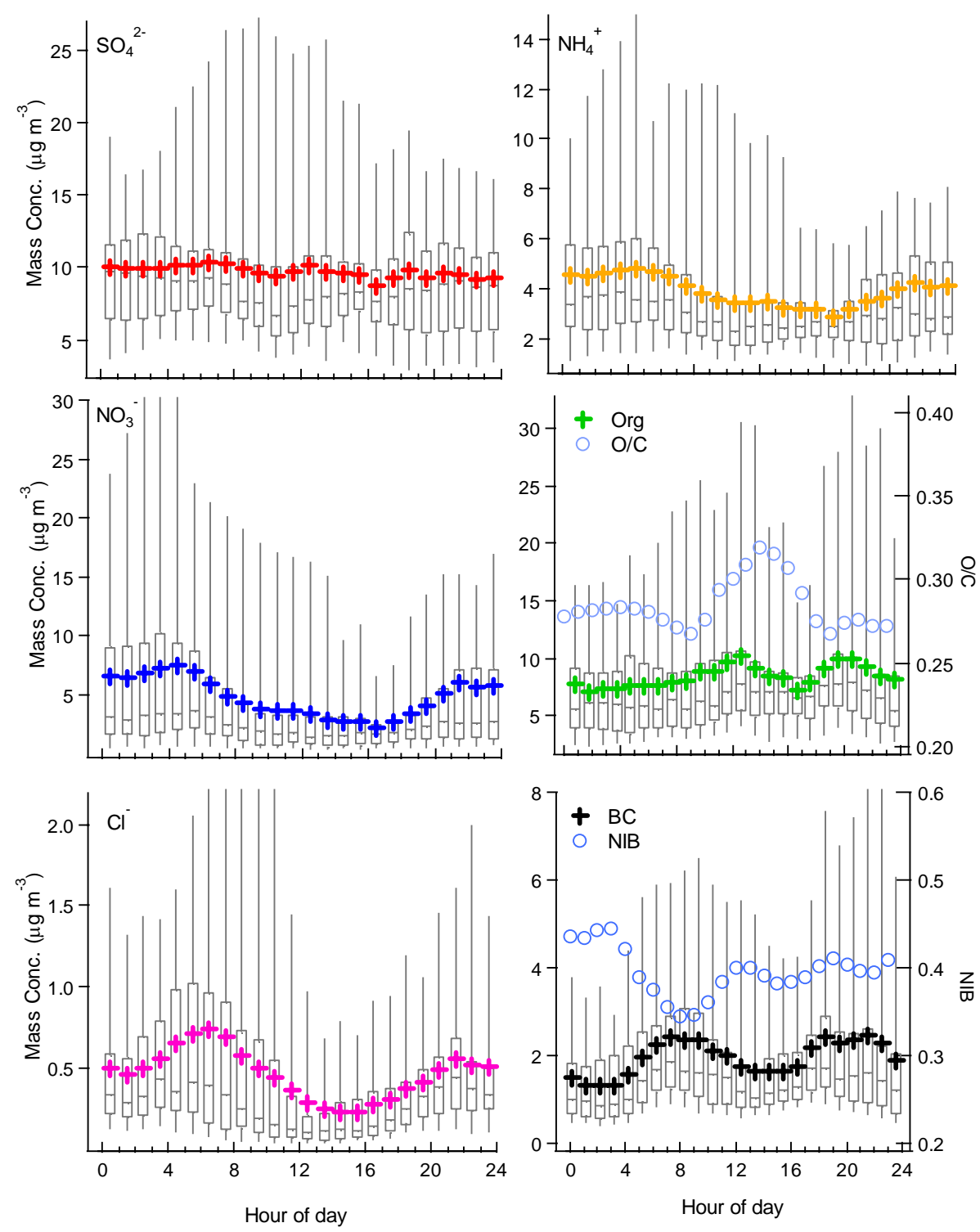

Fig. 3. Diurnal variation box plots of $\mathrm{PM}_{1}$ species. The upper and lower boundaries of boxes indicate the 75 th and 25 th percentiles; the line within the box marks the median; the whiskers above and below boxes indicate the 90th and 10th percentiles; and cross symbols represent the means.

factors and no more meaningful factors. The sensitivity of the three factor solution $\left(Q / Q_{\exp }=5.08\right)$ to rotation $(-3$ to 3 ) and to starting values (0-250) of the fitted parameters was also confirmed. Based on all of these tests, the three factor, $\mathrm{FPEAK}=0$, seed $=0$ solution was chosen as the optimal solution for the dataset in Shanghai. The three identified organic components included a hydrocarbon-like organic aerosol (HOA: $\mathrm{O} / \mathrm{C}=0.16$ ), a semi-volatile oxygenated organic aerosol (SV-OOA: $\mathrm{O} / \mathrm{C}=0.35$ ), a low-volatility oxygenated organic aerosol $(\mathrm{LV}-\mathrm{OOA}, \mathrm{O} / \mathrm{C}=0.65)$. Figure $4 \mathrm{a}$ shows the high resolution MS profiles of the three components and Fig. $4 \mathrm{~b}$ presents their time series together with those of the corresponding tracers in the campaign.
The HOA, SV-OOA and LV-OOA components have been frequently identified in previous factor analysis of AMS ambient aerosol datasets and typically attributed to fossil fuel combustion, fresh SOA and aged SOA, respectively (Aiken et al., 2009; Ulbrich et al., 2009; Jimenez et al., 2009; $\mathrm{Ng}$ et al., 2010; He et al., 2011). The representativeness of the three organic components identified in Shanghai was examined for three major characteristics: (1) The MS of HOA, SVOOA and LV-OOA featured ions of $\mathrm{C}_{n} \mathrm{H}_{2 n+1}^{+}$and $\mathrm{C}_{n} \mathrm{H}_{2 n-1}^{+}$, $\mathrm{C}_{\mathrm{x}} \mathrm{H}_{\mathrm{y}} \mathrm{O}_{\mathrm{z}}^{+}$with a lower fraction of $\mathrm{CO}_{2}^{+}, \mathrm{C}_{\mathrm{x}} \mathrm{H}_{\mathrm{y}} \mathrm{O}_{\mathrm{z}}^{+}$with a higher fraction of $\mathrm{CO}_{2}^{+}$, respectively; The $\mathrm{O} / \mathrm{C}$ ratios of them well fitted in the typical ranges identified previously for HOA (0.06-0.17), SV-OOA $(0.35 \pm 0.14)$ and LV-OOA 


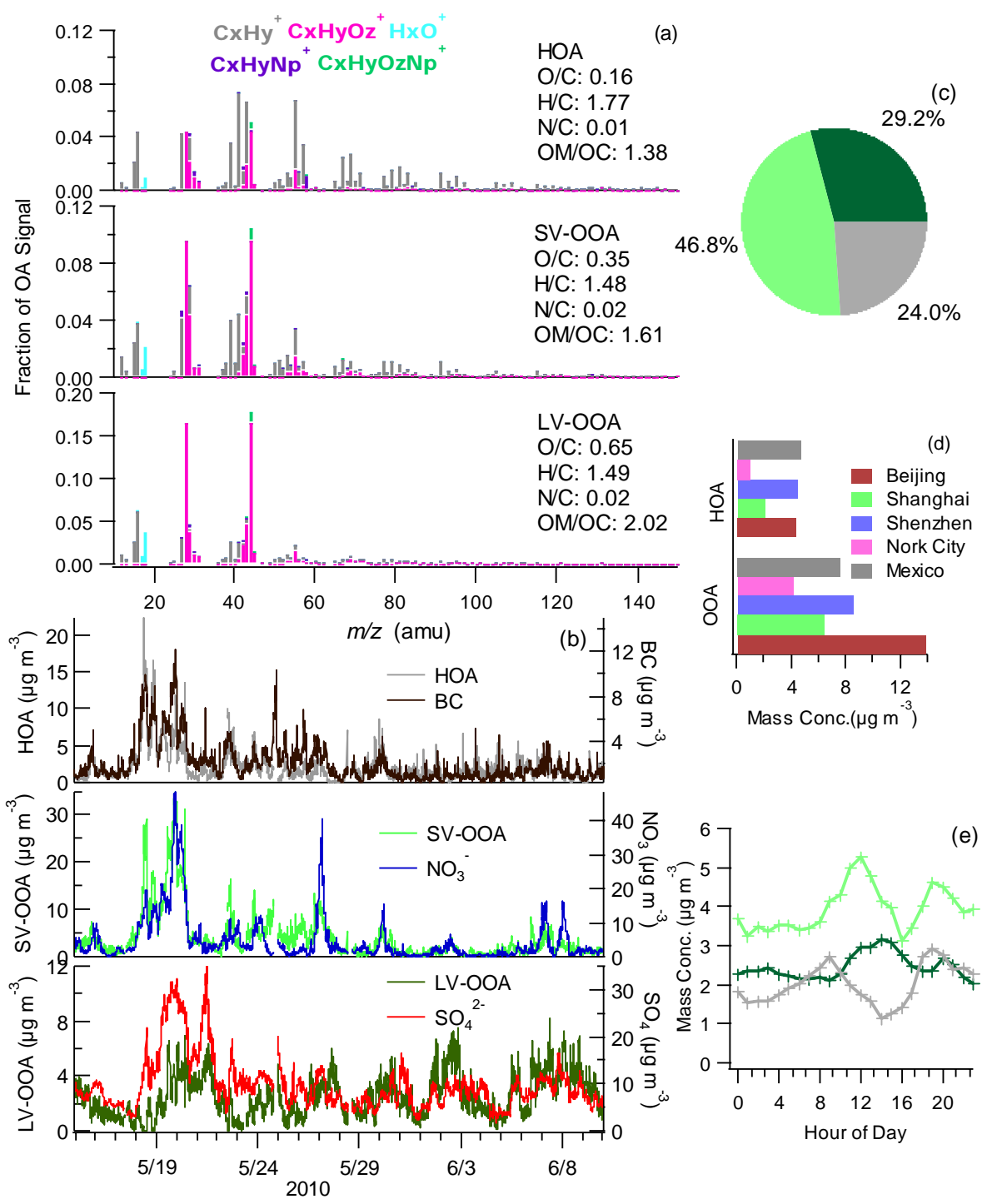

Fig. 4. (a) The MS profiles of the three organic components identified by PMF in this study; (b) time series of the organic components and relevant tracer species; (c) the average organic aerosol composition; (d) the comparison of HOA and OOA concentrations with other mega-cities; and (e) the mean diurnal variations of the organic components.

$(0.73 \pm 0.14)$, respectively; The time series of HOA, SV-OOA and LV-OOA correlated well with the corresponding tracers, i.e. $\mathrm{BC}$, nitrate and sulfate, respectively. More specification of this kind of judgment can be found in the literature (U1brich et al., 2009; He et al., 2011). On average, the HOA, SV-OOA and LV-OOA accounted for 24.0, 46.8 and $29.2 \%$ of the total organic mass, respectively, as shown in Fig. 4c. Both the average concentrations of HOA, as a surrogate of primary organic aerosol, and OOA (SV-OOA + LV-OOA), as a surrogate of SOA, in Shanghai were higher than those in New York but lower than those in Beijing, Shenzhen and Mexico City, as compared in Fig. 4d.

It should be noted that no biomass burning-related organic component was identified by PMF in this campaign, although biomass burning was ever found to be a significant source of fine particles in Shanghai in previous studies (J. Feng et al., 2006; Du et al., 2011) and the PMF analysis of HR-ToFAMS datasets successfully identified a biomass burning organic aerosol (BBOA) component in many field campaigns (e.g. Aiken et al., 2009; Huang et al., 2011b; He et al., 2011). This was most likely a result of the strict control measures for open field biomass burning events in the rural areas around Shanghai under the air quality assurance act for the World Expo. The little presence of $m / z 60$, a tracer ion fragment for primary biomass burning aerosols (Alfarra et al., 2007; Aiken et al., 2009), in the MS of each component in Fig. 4a also suggests that BBOA was not abundant enough to be distinguished in this campaign. A similar case of no BBOA 


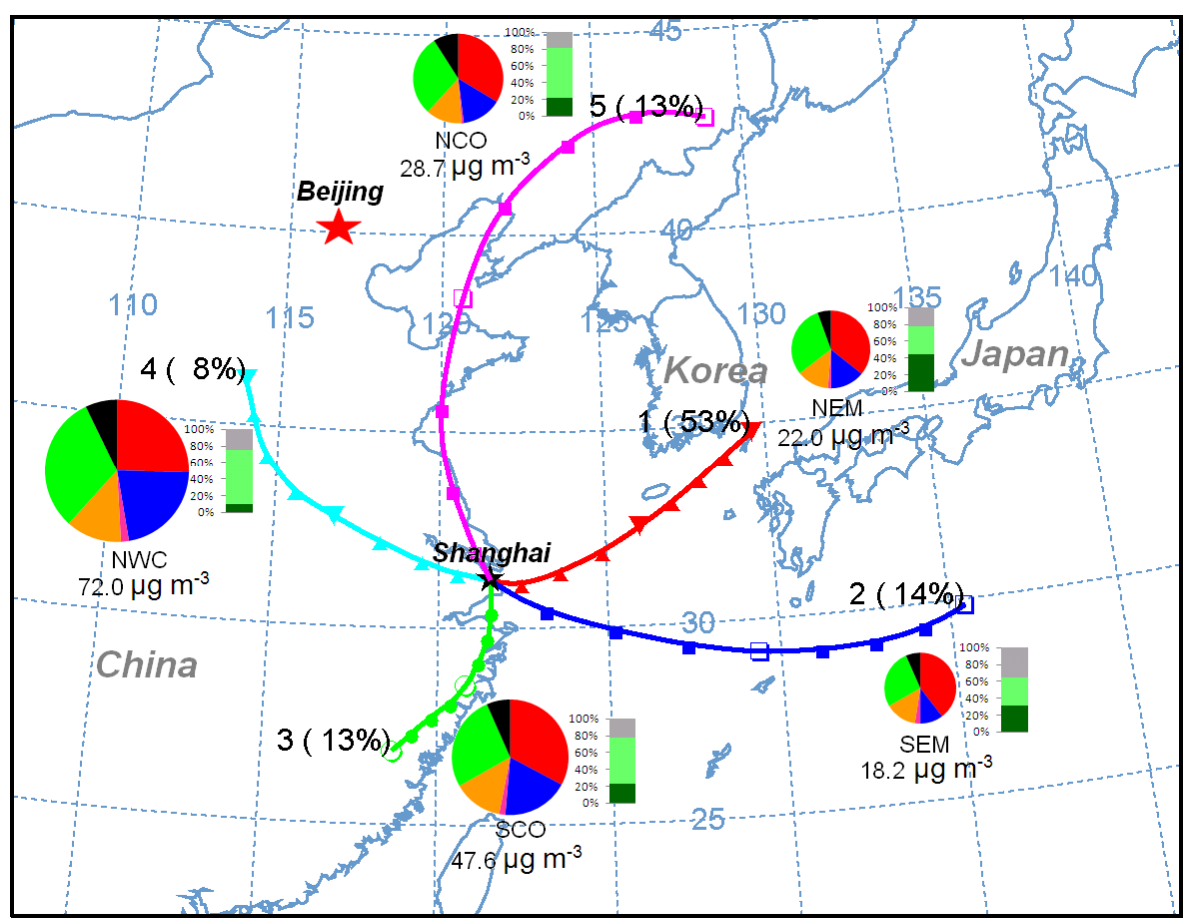

Fig. 5. Back trajectory clusters and the corresponding mean $\mathrm{PM}_{1}$ compositions during the campaign. The five clusters are northeasterly marine (NEM) BTs, southeasterly marine (SEM) BTs, southerly costal (SCO) BTs, northwesterly continental (NWC) BTs, and northerly coastal (NCO) BTs.

identified in organic aerosol was also observed previously during the 2008 Beijing Olympic Games due to its strict control measures on open field burning. These two unique cases could indicate that the significant contributions of BBOA to urban aerosols in China can be effectively reduced by controlling the open field burning events in the surrounding rural areas.

The average diurnal patterns of the three organic components, as shown in Fig. 4e, were alike in having a common two-peak shape while different in the occurring time of the peaks. HOA showed two broad peaks in the morning and evening, very similar to the diurnal pattern of BC. The morning peak of HOA occurred at about 9 a.m. due to the high morning traffic; the first peak of SV-OOA occurred at about 12 p.m., about $3 \mathrm{~h}$ later relative to HOA; and the first peak of LV-OOA occurred at about 2 p.m., $2 \mathrm{~h}$ later relative to $\mathrm{SV}$ OOA. Similar phenomena were also observed previously in the diurnal patterns of HOA, SV-OOA and LV-OOA in New York (Sun et al., 2011). This interesting time delay of the daytime peaks of the three organic components could imply a photochemical oxidizing process from HOA (and/or concurrently emitted gaseous organic pollutants) to SV-OOA to LV-OOA, which is well consistent with the recent finding that the aging of organic aerosol is a continuum in the atmosphere (Jimenez et al., 2009), and the responsible mechanisms need to be explored by modeling work in future. The changing scale of the evening peak of HOA is similar to that of the morning peak, while the changing scale of the second peak of SV-OOA is much smaller than that of the morning peak and the changing scale of the second peak of LVOOA is nearly negligible. This may suggest that although HOA and/or its concurrently emitted gaseous organic pollutants were also abundant in the atmosphere in the evening, the SV-OOA and LV-OOA could not be produced significantly without sunlight. The approximate occurring times of the secondary peaks of HOA, SV-OOA and LV-OOA indicate that these peaks were simultaneously caused by the changing of meteorology. Both the decreasing boundary layer and ambient temperature in the evening would favor the accumulation of semi-volatile particulate organic matter.

\subsection{Back trajectory analysis}

To explore the regional transport influence on $\mathrm{PM}_{1}$ loading and composition in the campaign, the HYbrid Single Particle Lagrangian Integrated Trajectory (HYSPLIT4) model developed by NOAA/ARL (Draxler and Rolph, 2003) was used to produce back trajectories (BT) of air mass arriving in Shanghai. 48-h back trajectories staring at $500 \mathrm{~m}$ above the ground level of Shanghai $\left(121.53^{\circ} \mathrm{E}, 31.23^{\circ} \mathrm{N}\right)$ were calculated every $6 \mathrm{~h}$ in the campaign, and then clustered according to their similarity in spatial distribution using the HYSPLIT4 software (Draxler et al., 2009). The five-cluster solution was found to be the optimum solution according 
to the change in total spatial variance, with the mean BT of each cluster presented in Fig. 5. The five clusters were named northeasterly marine (NEM) BTs, southeasterly marine (SEM) BTs, southerly costal (SCO) BTs, northwesterly continental (NWC) BTs, and northerly coastal (NCO) BTs, respectively, according to their spatial origins. In result, the NEM BTs were found to be the most frequent cluster, accounting for $51 \%$ of all the BTs.

The average $\mathrm{PM}_{1}$ compositions corresponding to the five BT clusters were then calculated and shown in Fig. 5. The NWC BTs represented the most polluted air mass origin with a mean $\mathrm{PM}_{1}$ mass concentration of $72.0 \mu \mathrm{g} \mathrm{m}^{-3}$, while the SEM BTs represented the cleanest air mass with a mean $\mathrm{PM}_{1}$ mass concentration of $18.2 \mu \mathrm{g} \mathrm{m}^{-3}$. This $\mathrm{PM}_{1}$ loading distribution pattern clearly indicates that the northwestern areas to Shanghai, i.e. China Central Plains, were a much polluted region and the highest $\mathrm{PM}_{1}$ loadings in Shanghai can be caused by pollutant regional transport from there. This finding is well consistent with the finding during the 2008 Beijing Olympic Games that the highest $\mathrm{PM}_{1}$ loadings in Beijing can be caused by southerly pollutant regional transport from the Central Plains. Therefore, both the Beijing and Shanghai campaigns identified the Central Plains as a critical pollutant source region of China. In terms of composition, the polluted NWC BTs had the highest fractions of OM and nitrate among the five clusters, indicating more severe organic and $\mathrm{NO}_{\mathrm{x}}$ pollution to the northwest of Shanghai. As to the organic composition, the three continent-related BT clusters (SCO, NWC and NCO) had much higher SV-OOA fractions than the two marine-related BT clusters (NEM and SEM), which had low levels of background pollutants and were thus more representative of local pollutions of Shanghai. For the polluted NWC BTs, SV-OOA accounted for up to $20.1 \%$ of the total $\mathrm{PM}_{1}$ mass. Based on the above BT analysis, it is clearly seen that the BT type is a vital factor influencing the $\mathrm{PM}_{1}$ loading and composition in Shanghai, and nitrate and SV-OOA were largely from regional transport in high fine particle pollution days of Shanghai.

\section{Conclusions}

Atmospheric $\mathrm{PM}_{1}$ particles were on-line measured by a HRToF-AMS and a SP2 between 15 May and 10 June during 2010 Shanghai World Expo. The high time resolution PM $_{1}$ mass concentration ranged from 5.5 to $155 \mu \mathrm{g} \mathrm{m}^{-3}$, with an average of $29.2 \mu \mathrm{g} \mathrm{m}^{-3}$. On average, sulfate and OM were the most abundant $\mathrm{PM}_{1}$ components, accounting for 33.3 and $28.7 \%$ of the total mass, respectively, followed by nitrate $(16.3 \%)$, ammonium $(13.4 \%)$, BC (6.7\%), and chloride $(1.6 \%)$. In addition, the contribution of nitrate to total $\mathrm{PM}_{1}$ mass showed an increasing trend with the increasing $\mathrm{PM}_{1}$ loading, implying the photochemical nature of high fine particle pollution in Shanghai. The average size distributions of the species measured by HR-ToF-AMS were all domi- nated by an accumulation mode at $\sim 450 \mathrm{~nm}$ in $D_{\text {va }}$. Calculations of organic elemental composition indicated an average $\mathrm{O} / \mathrm{C}$ ratio of 0.31 and an average $\mathrm{OM} / \mathrm{OC}$ ratio of 1.55 . The number fraction of internally mixed BC (NIB) was observed to have an average of $41.2 \%$, indicating that $\mathrm{BC}$ was dominated by fresh local emissions there. PMF analysis identified three components, including HOA, SV-OOA and LV-OOA, which on average accounted for $24.0,46.8$ and $29.2 \%$ of the total organic mass, respectively. The average diurnal patterns of the three organic components had a common two-peak shape while with interesting time delay from HOA to SVOOA to LV-OOA for the daytime peak, possibly implying a photochemical oxidizing process from HOA (and/or its concurrently emitted gaseous organic pollutants) to SV-OOA to LV-OOA. Back trajectory analysis indicated that the northwesterly continental air mass represented the most severe pollutant regional transport condition, with a high $\mathrm{PM}_{1}$ mass concentration of $72.0 \mathrm{\mu g} \mathrm{m}^{-3}$ and large regional transport of nitrate and SV-OOA.

Acknowledgements. This work was supported by the project of Air Quality Monitoring Campaign for 2010 Shanghai World Expo and the National Natural Science Foundation of China (40805049, 21177001).

Edited by: X. Tie

\section{References}

Aiken, A. C., DeCarlo, P. F., and Jimenez, J. L.: Elemental analysis of organic species with electron ionization high-resolution mass spectrometry, Anal. Chem., 79, 8350-8358, 2007.

Aiken, A. C., Decarlo, P. F., Kroll, J. H., Worsnop, D. R., Huffman, J. A., Docherty, K. S., Ulbrich, I. M., Mohr, C., Kimmel, J. R., Sueper, D., Sun, Y., Zhang, Q., Trimborn, A., Northway, M., Ziemann, P. J., Canagaratna, M. R., Onasch, T. B., Alfarra, M. R., Prevot, A. S., Dommen, J., Duplissy, J., Metzger, A., Baltensperger, U., and Jimenez, J. L.: O/C and OM/OC ratios of primary, secondary, and ambient organic aerosols with high-resolution time-of-flight aerosol mass spectrometry, Environ. Sci. Technol., 42, 4478-4485, 2008.

Aiken, A. C., Salcedo, D., Cubison, M. J., Huffman, J. A., DeCarlo, P. F., Ulbrich, I. M., Docherty, K. S., Sueper, D., Kimmel, J. R., Worsnop, D. R., Trimborn, A., Northway, M., Stone, E. A., Schauer, J. J., Volkamer, R. M., Fortner, E., de Foy, B., Wang, J., Laskin, A., Shutthanandan, V., Zheng, J., Zhang, R., Gaffney, J., Marley, N. A., Paredes-Miranda, G., Arnott, W. P., Molina, L. T., Sosa, G., and Jimenez, J. L.: Mexico City aerosol analysis during MILAGRO using high resolution aerosol mass spectrometry at the urban supersite (T0) - Part 1: Fine particle composition and organic source apportionment, Atmos. Chem. Phys., 9, 6633-6653, doi:10.5194/acp-9-6633-2009, 2009.

Alfarra, M. R., Coe, H., Allan, J. D., Bower, K. N., Boudries, H., Canagaratna, M. R., Jimenez, J. L., Jayne, J. T., Garforth, A. A., Li, S.-M., and Worsnop, D. R.: Characterization of urban and rural organic particulate in the lower Fraser valley using two aero- 
dyne aerosol mass spectrometers, Atmos. Environ., 38, 57455758, 2004

Alfarra, M. R., Prevot, A. S. H., Szidat, S., Sandradewi, J., Weimer, S., Lanz, V. A., Schreiber, D., Mohr, M., and Baltensperger, U.: Identification of the mass spectral signature of organic aerosols from wood burning emissions, Environ. Sci. Technol., 41, 57705777, 2007.

Allan, J. D., Alfarra, M. R., Bower, K. N., Williams, P. I., Gallagher, M. W., Jimenez, J. L., McDonald, A. G., Nemitz, E., Canagaratna, M. R., Jayne, J. T., Coe, H., and Worsnop, D. R.: Quantitative sampling using an Aerodyne AerosolMass Spectrometer. Part 2: Measurements of fine particulate chemical composition in two UK Cities, J. Geophys. Res.-Atmos., 108, 4091, doi:10.1029/2002JD002359, 2003.

Canagaratna, M. R., Jayne, J. T., Jimenez, J. L., Allan, J. D., Alfarra, M. R., Zhang, Q., Onasch, T. B., Drewnick, F., Coe, H., Middlebrook, A., Delia, A., Williams, L. R., Trimborn, A. M., Northway, M. J., DeCarlo, P. F., Kolb, C. E., Davidovits, P., and Worsnop, D. R.: Chemical and microphysical characterization of ambient aerosols with the aerodyne aerosol mass spectrometer, Mass Spectrom. Rev., 26, 185-222, 2007.

Chan, C. K. and Yao, X.: Air pollution in mega cities in China, Atmos. Environ., 42, 1-42, 2008.

Crounse, J. D., DeCarlo, P. F., Blake, D. R., Emmons, L. K., Campos, T. L., Apel, E. C., Clarke, A. D., Weinheimer, A. J., McCabe, D. C., Yokelson, R. J., Jimenez, J. L., and Wennberg, P. O.: Biomass burning and urban air pollution over the Central Mexican Plateau, Atmos. Chem. Phys., 9, 4929-4944, doi:10.5194/acp-9-4929-2009, 2009.

DeCarlo, P. F., Kimmel, J. R., Trimborn, A., Northway M. J., Jayne, J. T., Aiken, A. C., Gonin, M., Fuhrer, K., Horvath, T., Docherty, K. S., Worsnop, D. R., and Jimenez, J. L.: Fielddeployable, high-resolution time-of-flight aerosol mass spectrometer, Anal. Chem., 78, 8281-8289, 2006.

Draxler, R. R. and Rolph, G. D.: HYSPLIT (HYbrid Single-Particle Lagrangian Integrated Trajectory) Model access via NOAA ARL READY Website (http://www.arl.noaa.gov/ready/hysplit4.html), NOAA Air Resources Laboratory, Silver Spring, MD, USA (last access: August 2011) 2003.

Draxler, R., Stunder, B., Rolph, G., Stein, A., and Taylor, A.: HYSPLIT4 user's guide, Version 4.9, http://ready.arl.noaa.gov/ HYSPLIT.php (last access: August 2011), 2009.

Drewnick, F., Hings, S. S., DeCarlo, P., Jayne, J. T., Gonin, M., Fuhrer, K., Weimer, S., Jimenez, J. L., Demerjian, K. L., Borrmann, S., and Worsnop, D. R.: A new time-of-flight aerosol mass spectrometer (TOF-AMS)-Instrument description and first field deployment, Aerosol. Sci. Tech., 39, 637-658, 2005.

Du, H., Kong, L., Cheng, T., Chen, J., Du, J., Li, L., Xia, X., Leng, C., and Huang, G.: Insights into summertime haze pollution events over Shanghai based on online water-soluble ionic composition of aerosols, Atmos. Environ., 45, 5131-5137, 2011.

Feng, J., Chak, C. K., Fang, M., Hu, M., He, L., and Tang, X.: Characteristics of organic matter in $\mathrm{PM}_{2.5}$ in Shanghai, Chemosphere, 64, 1393-1400, 2006.

Feng, Y., Chen, Y., Guo, H., Zhi, G., Xiong, S., Li, J., Sheng, G., and $\mathrm{Fu}$, J.: Characteristics of organic and elemental carbon in $\mathrm{PM}_{2.5}$ samples in Shanghai, China, Atmos. Res., 92, 434-442, 2009.

He, L. Y., Huang, X. F., Xue, L., Hu, M., Lin, Y., Zheng, J., Zhang, R., and Zhang, Y. H.: Submicron aerosol analysis and organic source apportionment in an urban atmosphere in Pearl River Delta of China using high-resolution aerosol mass spectrometry, J. Geophys. Res., 116, D12304, doi:10.1029/2010JD014566, 2011.

Huang, X.-F., He, L.-Y., Hu, M., Canagaratna, M. R., Sun, Y., Zhang, Q., Zhu, T., Xue, L., Zeng, L.-W., Liu, X.-G., Zhang, Y.-H., Jayne, J. T., Ng, N. L., and Worsnop, D. R.: Highly time-resolved chemical characterization of atmospheric submicron particles during 2008 Beijing Olympic Games using an Aerodyne High-Resolution Aerosol Mass Spectrometer, Atmos. Chem. Phys., 10, 8933-8945, doi:10.5194/acp-10-8933-2010, 2010.

Huang, X. F., Gao, R. S., Schwarz, J. P., He, L. Y., Fahey, D. W., Watts, L. A., McComiskey, A., Cooper, O. R., Sun, T. L., Zeng, L. W., Hu, M., and Zhang, Y. H.: Black carbon measurements in the Pearl River Delta region of China, J. Geophys. Res.-Atmos., 116, D12208, doi:10.1029/2010jd014933, 2011a.

Huang, X.-F., He, L.-Y., Hu, M., Canagaratna, M. R., Kroll, J. H., Ng, N. L., Zhang, Y.-H., Lin, Y., Xue, L., Sun, T.-L., Liu, X.-G., Shao, M., Jayne, J. T., and Worsnop, D. R.: Characterization of submicron aerosols at a rural site in Pearl River Delta of China using an Aerodyne High-Resolution Aerosol Mass Spectrometer, Atmos. Chem. Phys., 11, 1865-1877, doi:10.5194/acp-11-18652011, 2011b.

Huang, X. F., Sun, T. L., Zeng, L. W., Yu, G. H., and Luan, S. J.: Black carbon aerosol characterization in a coastal city in South China using a single particle soot photometer, Atmos. Environ., 51, 21-28, 2012.

Jayne, J. T., Leard, D. C., Zhang, X. F., Davidovits, P., Smith, K. A., Kolb, C. E., and Worsnop, D. R.: Development of an aerosol mass spectrometer for size and composition analysis of submicron particles, Aerosol. Sci. Tech., 33, 49-70, 2000.

Jimenez, J. L., Jayne, J. T., Shi, Q., Kolb, C. E., Worsnop, D. R., Yourshaw, I., Seinfeld, J. H., Flagan, R. C., Zhang, X.-F., Smith, K. A., Morris, J. W., and Davidovits, P.: Ambient aerosol sampling using the Aerodyne Aerosol Mass Spectrometer, J. Geophys. Res.-Atmos., 108, 8425, doi:10.1029/2001JD001213, 2003.

Jimenez, J. L., Canagaratna, M. R., Donahue, N. M., Prevot, A. S. H., Zhang, Q., Kroll, J. H., DeCarlo, P. F., Allan, J. D., Coe, H., Ng, N. L., Aiken, A. C., Docherty, K. S., Ulbrich, I. M., Grieshop, A. P., Robinson, A. L., Duplissy, J., Smith, J. D., Wilson, K. R., Lanz, V. A., Hueglin, C., Sun, Y. L., Tian, J., Laaksonen, A., Raatikainen, T., Rautiainen, J., Vaattovaara, P., Ehn, M., Kulmala, M., Tomlinson, J. M., Collins, D. R., Cubison, M. J., Dunlea, E. J., Huffman, J. A., Onasch, T. B., Alfarra, M. R., Williams, P. I., Bower, K., Kondo, Y., Schneider, J., Drewnick, F., Borrmann, S., Weimer, S., Demerjian, K., Salcedo, D., Cottrell, L., Griffin, R., Takami, A., Miyoshi, T., Hatakeyama, S., Shimono, A., Sun, J. Y., Zhang, Y. M., Dzepina, K., Kimmel, J. R., Sueper, D., Jayne, J. T., Herndon, S. C., Trimborn, A. M., Williams, L. R., Wood, E. C., Middlebrook, A. M., Kolb, C. E., Baltensperger, U., and Worsnop, D. R.: Evolution of organic aerosols in the atmosphere, Science, 326, 1525-1529, 2009.

Ng, N. L., Canagaratna, M. R., Zhang, Q., Jimenez, J. L., Tian, J., Ulbrich, I. M., Kroll, J. H., Docherty, K. S., Chhabra, P. S., Bahreini, R., Murphy, S. M., Seinfeld, J. H., Hildebrandt, L., Donahue, N. M., DeCarlo, P. F., Lanz, V. A., Prévôt, A. S. H., Dinar, E., Rudich, Y., and Worsnop, D. R.: Organic aerosol 
components observed in Northern Hemispheric datasets from Aerosol Mass Spectrometry, Atmos. Chem. Phys., 10, 46254641, doi:10.5194/acp-10-4625-2010, 2010.

Paatero, P. and Hopke, P. K.: Discarding or downweighting highnoise variables in factor analytic models, Anal. Chim. Acta, 490, 277-289, 2003.

Paatero, P. and Tapper, U.: Positive Matrix Factorization-a Nonnegative Factor Model with Optimal Utilization of Error-Estimates of Data Values, Environmetrics, 5, 111-126, 1994.

Parrish, D. D. and Zhu, T.: Clean Air for Megacities, Science, 326, 674-675, 2009.

Schwarz, J. P., Gao, R. S., Fahey, D. W., Thomson, D. S., Watts, L. A., Wilson, J. C., Reeves, J. M., Darbeheshti, M., Baumgardner, D. G., Kok, G. L., Chung, S. H., Schulz, M., Hendricks, J., Lauer, A., Karcher, B., Slowik, J. G., Rosenlof, K. H., Thompson, T. L., Langford, A. O., Loewenstein, M., and Aikin, K. C.: Single-particle measurements of midlatitude black carbon and light-scattering aerosols from the boundary layer to the lower stratosphere, J. Geophys. Res.-Atmos., 111, D16207, doi:10.1029/2006jd007076, 2006.

Schwarz, J. P., Gao, R. S., Spackman, J. R., Watts, L. A., Thomson, D. S., Fahey, D. W., Ryerson, T. B., Peischl, J., Holloway, J. S., Trainer, M., Frost, G. J., Baynard, T., Lack, D. A., de Gouw, J. A., Warneke, C., and Del Negro, L. A.: Measurement of the mixing state, mass, and optical size of individual black carbon particles in urban and biomass burning emissions, Geophys. Res. Lett., 35, L13810, doi:10.1029/2008g1033968, 2008a.
Schwarz, J. P., Spackman, J. R., Fahey, D. W., Gao, R. S., Lohmann, U., Stier, P., Watts, L. A., Thomson, D. S., Lack, D. A., Pfister, L., Mahoney, M. J., Baumgardner, D., Wilson, J. C., and Reeves, J. M.: Coatings and their enhancement of black carbon light absorption in the tropical atmosphere, J. Geophys. Res.-Atmos., 113, D03203, doi:10.1029/2007jd009042, 2008 b.

Sun, Y.-L., Zhang, Q., Schwab, J. J., Demerjian, K. L., Chen, W.N., Bae, M.-S., Hung, H.-M., Hogrefe, O., Frank, B., Rattigan, O. V., and Lin, Y.-C.: Characterization of the sources and processes of organic and inorganic aerosols in New York city with a high-resolution time-of-flight aerosol mass apectrometer, Atmos. Chem. Phys., 11, 1581-1602, doi:10.5194/acp-11-15812011, 2011.

Ulbrich, I. M., Canagaratna, M. R., Zhang, Q., Worsnop, D. R., and Jimenez, J. L.: Interpretation of organic components from Positive Matrix Factorization of aerosol mass spectrometric data, Atmos. Chem. Phys., 9, 2891-2918, doi:10.5194/acp-9-2891-2009, 2009.

Ye, B. M., Ji, X. L., Yang, H. Z., Yao, X. H., Chan, C. K., Cadle, S. H., Chan, T., and Mulawa, P. A.: Concentration and chemical composition of $\mathrm{PM}_{2.5}$ in Shanghai for a 1-year period, Atmos. Environ., 37, 499-510, 2003.

Zhang, Q., Worsnop, D. R., Canagaratna, M. R., and Jimenez, J. L.: Hydrocarbon-like and oxygenated organic aerosols in Pittsburgh: insights into sources and processes of organic aerosols, Atmos. Chem. Phys., 5, 3289-3311, doi:10.5194/acp-5-32892005, 2005. 